\title{
New 1,3,4-Oxadiazole Based Photosensitizers for Dye Sensitized Solar Cells
}

\author{
Umer Mehmood, ${ }^{1,2,3}$ Ibnelwaleed A. Hussein, ${ }^{3,4}$ and Muhammad Daud ${ }^{3}$ \\ ${ }^{1}$ Center of Research Excellence in Renewable Energy, Research Institute, King Fahd University of Petroleum \& Minerals (KFUPM), \\ P.O. Box 5050, Dhahran 31261, Saudi Arabia \\ ${ }^{2}$ Polymer and Process Engineering Department, University of Engineering \& Technology Lahore, Lahore 54000, Pakistan \\ ${ }^{3}$ Department of Chemical Engineering, King Fahd University of Petroleum \& Minerals (KFUPM), P.O. Box 5050, \\ Dhahran 31261, Saudi Arabia \\ ${ }^{4}$ Gas Processing Center, College of Engineering, Qatar University, P.O. Box 2713, Doha, Qatar
}

Correspondence should be addressed to Ibnelwaleed A. Hussein; ihussein@qu.edu.qa

Received 16 September 2015; Accepted 25 October 2015

Academic Editor: Vishal Mehta

Copyright (C) 2015 Umer Mehmood et al. This is an open access article distributed under the Creative Commons Attribution License, which permits unrestricted use, distribution, and reproduction in any medium, provided the original work is properly cited.

1,3,4-Oxadiazole based photosensitizers with biphenyl, naphthalene, anthracene, and triphenylamine as the electron-donating moiety were synthesized for solar cell applications. In these photosensitizers, cyano groups were introduced as the electron acceptor and the anchor group because of their high electron-withdrawing ability and strong bonding to the semiconductor. Oxadiazole isomers were used as the $\pi$-conjugation system, which bridges the donor-acceptor systems. The electrochemical and optical properties of the sensitizers were investigated both in their native form and upon incorporation into dye sensitized solar cells. The results of UV-visible absorption spectroscopy, electrochemical impedance spectroscopic measurements, and photocurrent voltage characteristics indicate that 1,3,4-oxadiazole pi-spacer with the anthracene moiety has the highest efficiency of $2.58 \%$. Density functional theory was employed to optimize the structures of the sensitizers and the $\mathrm{TiO}_{2}$ cluster.

\section{Introduction}

The wide spread application of the photovoltaic (PV) cells is limited mainly due to their high cost to energy output ratio. PV cells are generally classified as inorganic based cells and organic based ones. Inorganic PV cells (Si or quantum dots based solar cells) cost has dropped a lot in the last decades but is still noncompetitive compared to conventional electricity production sources. The motive to achieve high cost/efficiency ratios derived the emergence of the thin film dye sensitized solar cell. It was developed by O'Regan and Grätzel in 1991. The efficiency of this PV cell, which became known as dye sensitized solar cell (DSSC), was reported as 7.1 to $7.9 \%$ [1]. DSSCs have got attention due to an ideal tradeoff between efficiency and cost performance [2-5].

The dye, which is the major component of the DSSC, absorbs sunlight and produces excitons $[6,7]$. It is chemically bonded to the porous surface of a semiconductor. Currently, DSSCs based on ruthenium(II) polypyridyl complexes have the best conversion efficiencies (PCE) of $11 \%$ under standard (Global Air Mass 1.5) illumination [8-10]. But it is still low for commercial applications. The low absorption of light in the $\mathrm{red} /$ near infrared region (NIR) is the major drawback in the ruthenium based sensitizers that limits the further improvement in efficiency. To overcome these problems, metal-free organic sensitizers have been developed [11]. The basic structural unit of organic dye is donor- $\pi$ spacer-acceptor. Substituents acting as the donor and the acceptor are separated by a $\pi$-conjugated spacer. The studies suggest that the donor groups to form efficient sensitizers should be selected from the electron rich aryl amines family including phenylamine, aminocoumarin, indoline, (difluorenyl)triphenylamine, and biphenyl. The $\pi$-conjugated connector must be selected from compounds containing thiophene and oxadiazole units 


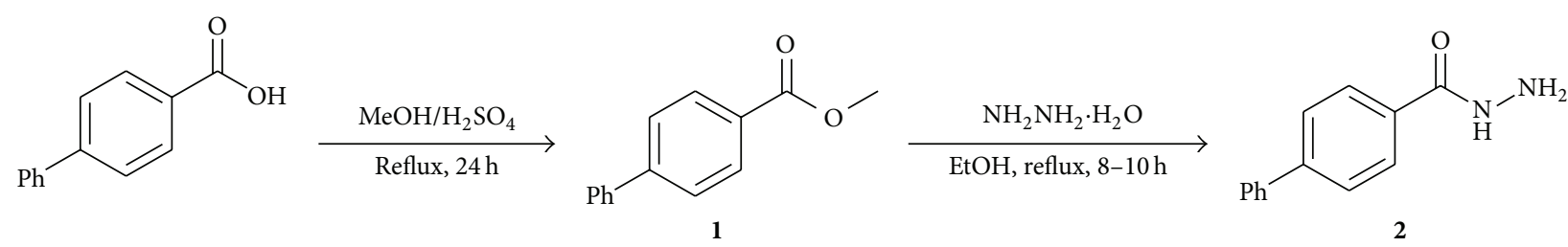<smiles>[R][R16]([H])([H])CC(=O)c1cccs1</smiles><smiles>c1ccc(-c2nnc(-c3cccs3)o2)cc1</smiles>

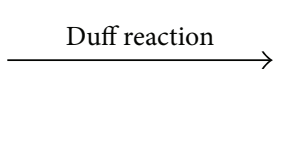<smiles>O=Cc1ccc(-c2nnc(-c3ccc(-c4ccccc4)cc3)o2)s1</smiles><smiles>N#C/C(=C\c1ccc(-c2nnc(-c3ccc(-c4ccccc4)cc3)o2)s1)C(=O)O</smiles>

SCHeme 1: Synthesis of novel dyes.

due to their outstanding charge transfer characteristics. Acrylic acid group is considered the best acceptor moiety [12]. Tian et al. synthesized methylthiophene based photosensitizers for high-performance DSSCs. They introduced vinyl unit as pi-bridge and found that the DSSC assembled with 2-cyano-3-(5-(4-(diphenylamino)phenyl)-4methylthiophenyl-2-yl) acrylic acid showed an efficiency of $8.27 \%$ under simulated AM $1.5 \mathrm{G}$ solar irradiation $\left(100 \mathrm{~mW} \mathrm{~cm}^{2}\right)$ [13]. Mao et al. synthesized a series of new metal-free organic dyes with either a boron dipyrromethene (BODIPY) phenylene or thiophene as a pi-conjugated bridge. The structure-property relationship of these dyes shows that the introduction of a methoxy group as the donor and a BODIPY thiophene unit as the pi-conjugated bridge are favorable to improve the efficiency of DSSCs [14]. Diketopyrrolopyrrole (DPP) sensitizers were synthesized by Qu et al. The sensitizer containing diketopyrrolopyrrole moiety as the pi-bridge exhibited good stability and better photovoltaic performance of up to $4.41 \%$ power conversion efficiency [15].

DFT/TD-DFT is an effective tool to investigate the ground and excited state properties of photosensitizer complexes as compared to other high level quantum approaches because the computed orbitals are suitable for the typical MO-theoretical analyses and interpretations [16]. Many theoreticians have successfully applied this approach in the designing of photosensitizers [17-24].

\section{Computer Simulation}

Amsterdam Density Functional (ADF) program (2013.01) was used to perform the DFT calculations. Generalized gradient approximation (GAD) at OLYP level with triple- $\zeta$ polarization basis function was used to optimize structures of
$\mathrm{TiO}_{2}$ and dyes. Relativistic effects were considered in all the calculations by applying zero order regular approximation in its scalar approximation $[21,22,25]$.

\section{Synthesis of Dyes}

Novel dyes were synthesized according to Scheme 1.

Step 1 (see Scheme 2(a): synthesis of ester (1)). A solution of biphenyl-4-carboxylic acid $(5 \mathrm{~g})$ in methanol $(25 \mathrm{~mL})$ in the presence of a catalytic amount of sulfuric acid $(0.5 \mathrm{~mL})$ was heated under reflux for $24 \mathrm{~h}$. The mixture was cooled to room temperature and then concentrated in vacuo. The resulting residue was diluted with water $(50 \mathrm{~mL})$ and extracted with ethyl acetate $(2 \times 50 \mathrm{~mL})$. The combined organic layers were washed with saturated sodium bicarbonate solution followed by water. The organic layer was dried over sodium sulfate and concentrated under reduced pressure to give the pure ester 1 in quantitative yield.

Step 2 (see Scheme 2(b): synthesis of hydrazide (2)). To a stirred solution of methyl biphenyl-4-carboxylate $(1,5 \mathrm{~g})$ in ethanol $(50 \mathrm{~mL})$, hydrazine monohydrate ( $100 \%$ solution) $(24 \mathrm{~g})$ was added. The resulting mixture was stirred at $80^{\circ} \mathrm{C}$ for $8 \mathrm{~h}$ and then concentrated under reduced pressure. The residue was diluted with ice cooled water $(50 \mathrm{~mL})$ and the solid was filtered and washed with water $(2 \times 50 \mathrm{~mL})$. The title compound was obtained as a pale amorphous solid in $88 \%$ yield.

Step 3 (see Scheme 2(c): synthesis of 1,3,4-oxadiazole (3)). To a mixture of hydrazide $(2,3.5 \mathrm{~g})$ and thiophene-2-carboxylic 
<smiles>COC(=O)c1ccc(-c2ccccc2)cc1</smiles>

(a)<smiles>CCOC(N)(N)CC(N)=O</smiles><smiles>NNC(=O)c1ccc(-c2ccccc2)cc1</smiles>

2<smiles>c1ccc(-c2ccc(-c3nnc(-c4cccs4)o3)cc2)cc1</smiles>

3<smiles>O=Cc1ccc(-c2nnc(-c3ccc(-c4ccccc4)cc3)o2)s1</smiles>

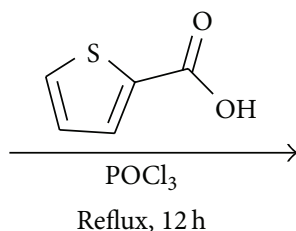

(c)

\section{Duff reaction}

(d)<smiles>c1ccc(-c2ccc(-c3nnc(-c4cccs4)o3)cc2)cc1</smiles><smiles>O=Cc1ccc(-c2nnc(-c3ccc(-c4ccccc4)cc3)o2)s1</smiles>

4<smiles>N#C/C(=C\c1ccc(-c2nnc(-c3ccc(-c4ccccc4)cc3)o2)s1)C(=O)O</smiles>

(e)

Scheme 2

acid (2.1 g), $\mathrm{POCl}_{3}(20 \mathrm{~mL})$ was added slowly at room temperature and the resulting mixture was stirred for $2 \mathrm{~h}$ at $110^{\circ} \mathrm{C}$. After the solution was cooled, excess $\mathrm{POCl}_{3}$ was removed under reduced pressure. The residue was diluted with water and then neutralized with aqueous sodium bicarbonate. The white precipitate was collected by filtration and washed with water. The resulting solid ( $4.8 \mathrm{~g}$ ) was further purified by column chromatography to give the pure oxadiazole $(4 \mathrm{~g})$.

Step 4 (see Scheme 2(d): formylation of thiophene ring by duff reaction (4)). A mixture of oxadiazole $(3,4 \mathrm{~g})$, hexamethylenetetramine $(8 \mathrm{~g})$ in $40 \mathrm{~mL}$ of trifluoroacetic acid was heated under reflux $\left(90-110^{\circ} \mathrm{C}\right)$. The progress of the reaction was monitored by TLC. Up on completion, the mixture was quenched with saturated sodium bicarbonate solution. The precipitated solids were filtered and then washed with water. The resulting solid was purified by column chromatography to give the desired aldehyde 4 (2.5 g).

Step 5 (see Scheme 2(e): synthesis of cyanoacrylic acid 5 through knoevenagel condensation (5)). To a solution of carboxaldehyde 4 ( $2 \mathrm{~g}$ ) and ammonium acetate ( 0.1 equiv.) in acetic acid $(20 \mathrm{~mL})$, cyanoacetic acid was added (1.1 equiv.). The resulting mixture was heated under reflux for $4 \mathrm{~h}$ and the progress of the reaction was monitored by TLC. After completion, the mixture was cooled and diluted with ice water. The precipitate 


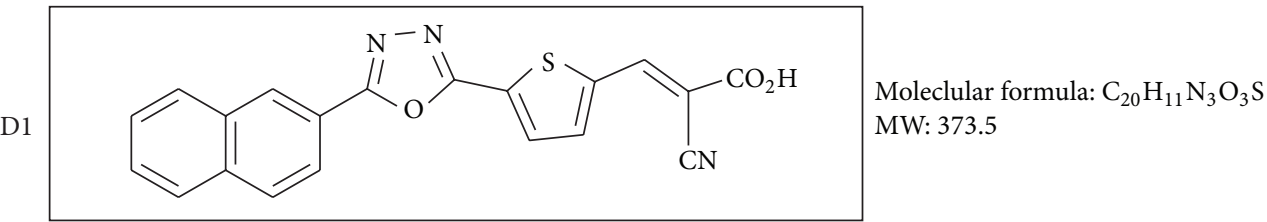

(E)-2-Cyano-3-(5-(5-(naphthalene-2-yl)-1,3,4-oxadiazole-2-yl)thiophene-2-yl)acrylic acid

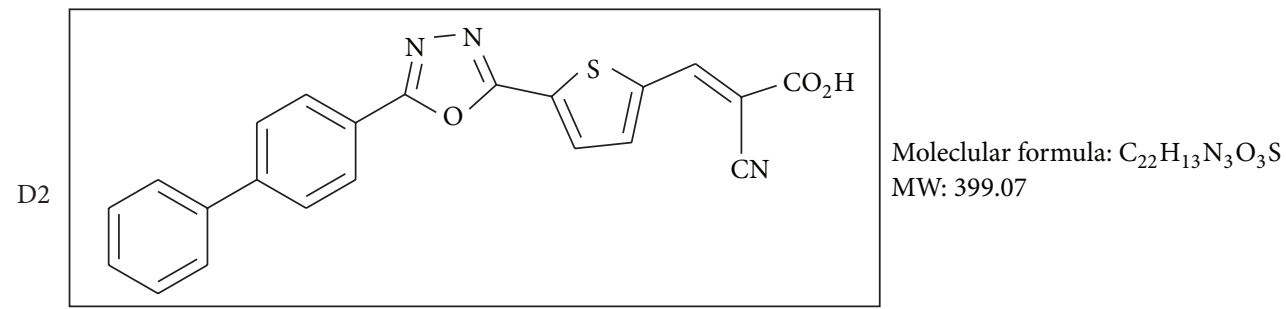

(E)-3-(5-(5-([1,1'-Biphenyl]-4-yl)-1,3,4-oxadiazole-2-yl)thiophene-2-yl)-2-cyanoacrylic acid

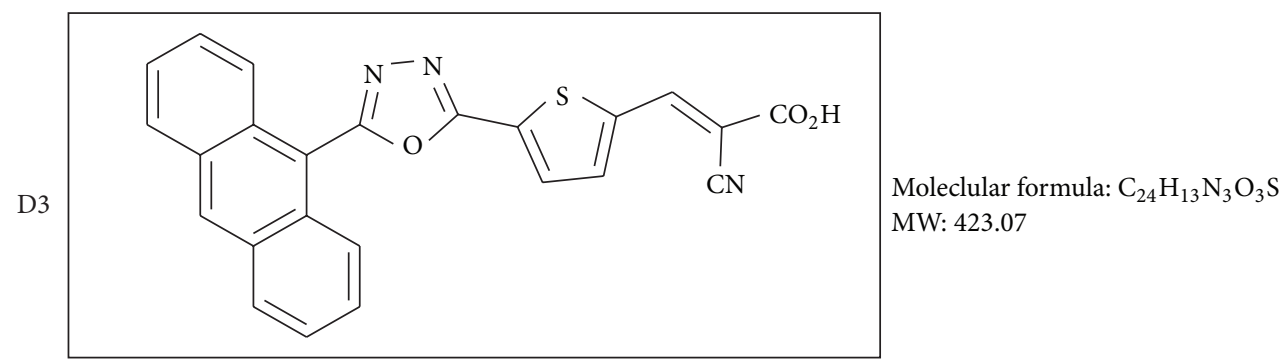

(E)-3-(5-(5-(Anthracene-9-yl)-1,3,4-oxadiazole-2-yl)thiophene-2-yl)-2-cyanoacrylic acid

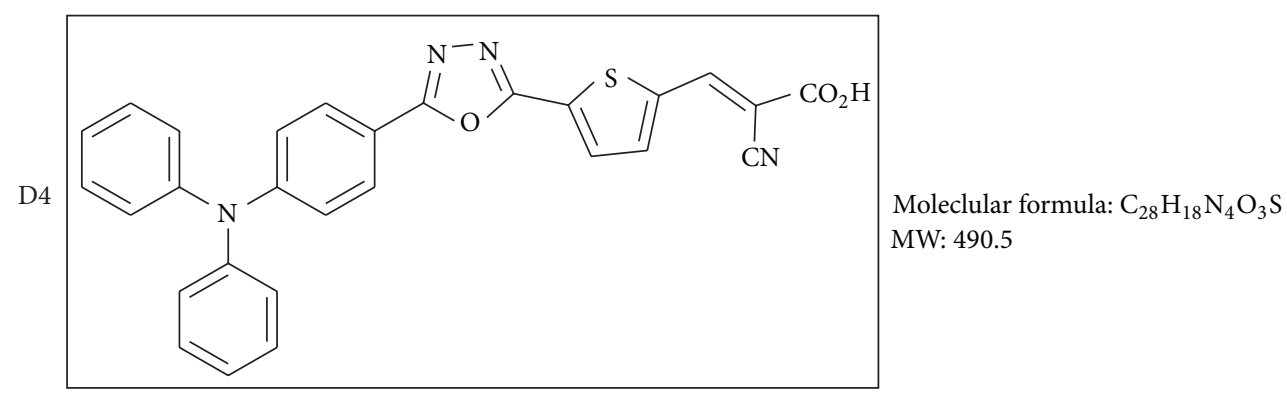

(E)-2-Cyano-3-(5-(5-(4-(diphenylamino)phenyl)-1,3,4-oxadiazole-2-yl)thiophene-2-yl)acrylic acid

FIGURE 1: Structures of the novel 1,3,4-oxadiazole based photosensitizers.

was filtered and washed with water. The resulting solid was recrystallized from toluene: methanol mixture $(9: 1)$ to afford the required dye 5 in pure form.

All other dyes (D1, D3, and D4) were prepared in the same manner. The structure and names of the dyes are shown in Figure 1.

\section{Fabrication and Characterization of DSSCs}

A $2 \mathrm{mM}$ solution of each dye was prepared in chloroform. $\mathrm{TiO}_{2}$ paste was deposited on conductive glass substrate and then sintered at $450^{\circ} \mathrm{C}$ for 30 minutes. The electrodes were immersed in the dye solution for 24 hours. After sensitization, the samples were washed with ethanol to eliminate unanchored dye. A platinum coated counter electrode was prepared by depositing platinum paste (Plasticol T, Solaronix) on FTO glass substrate and then heated at $450^{\circ} \mathrm{C}$ for $10 \mathrm{~min}$ utes. Then, DSSCs were fabricated employing the sensitized anode, counter electrode, $60 \mu \mathrm{m}$ sealing spacer (Meltonix 1170 , Solaronix), and $\mathrm{I}^{-} / \mathrm{I}_{3}{ }^{-}$redox couple electrolyte prepared in methoxypropionitrile with a $50 \mathrm{mM}$ redox concentration (Iodolyte Z-50, Solaronix). The visible spectra of dyes in methanol and anchored to $\mathrm{TiO}_{2}$ films at glass substrates were recorded with JASCO-670 UV/VIS spectrophotometer. Keithley 2400 Source Meter was used to measure the $I-V$ characteristics of the DSSCs using IV-5 solar simulator ( $\mathrm{Sr}$ \#83, PV Measurement, Inc.) at AM1.5G $\left(100 \mathrm{mWcm}^{-2}\right)$. The silicon solar cell was used as a reference for calibration. The EIS was measured in dark conditions of illumination via BioLogic SAS (VMP3, s/n: 0373), with an AC signal of $10 \mathrm{mV}$ in amplitude, in the frequency range between $10 \mathrm{~Hz}$ and $500 \mathrm{KHz}$. 


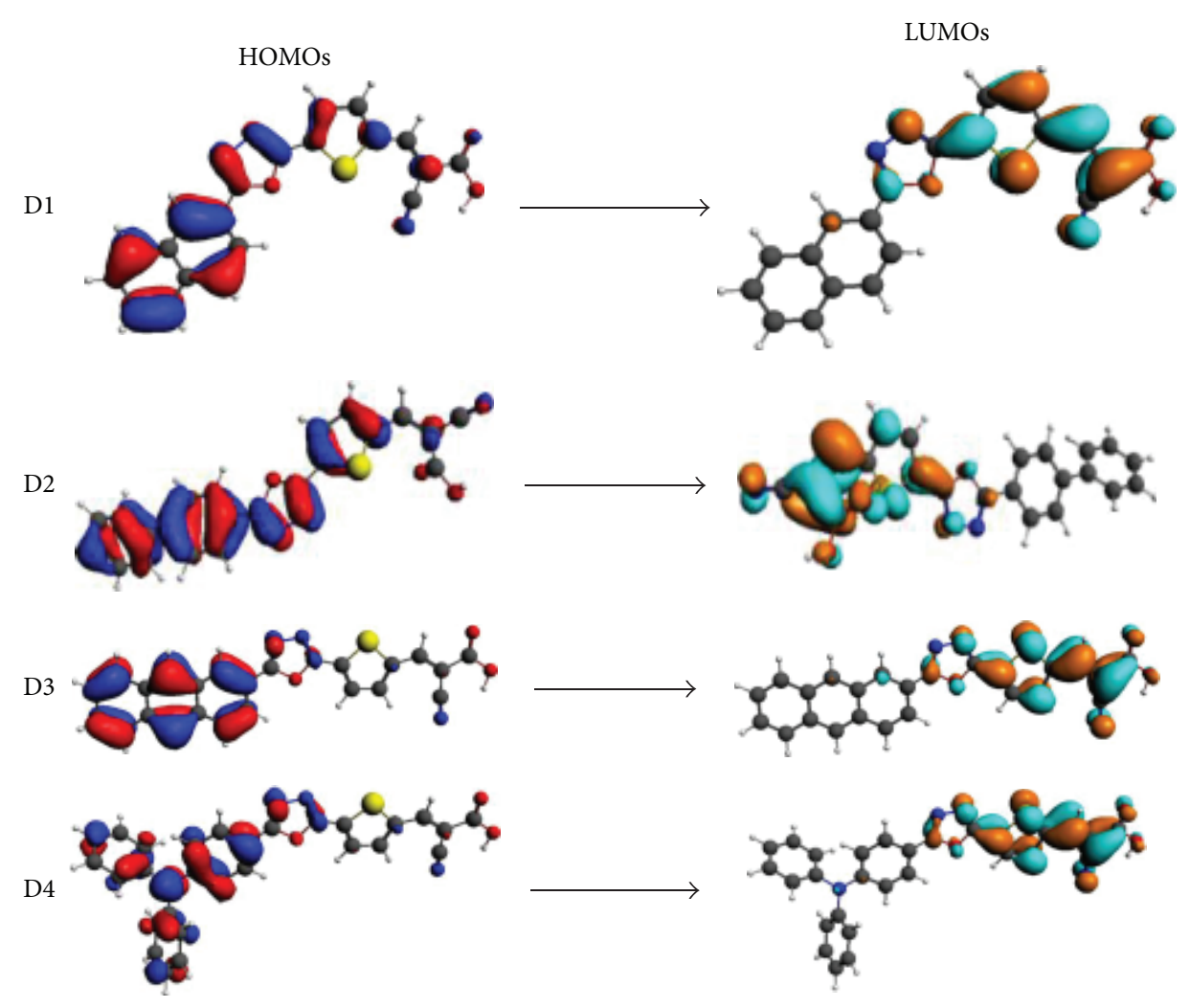

FIGURE 2: Simulated HOMOs and LUMOs of the dyes.

TABLE 1: FMO and band gaps of dyes D1 to D4.

\begin{tabular}{lccc}
\hline Dyes & LUMOs $(\mathrm{eV})$ & HOMOs $(\mathrm{eV})$ & Band gap $(\mathrm{eV})$ \\
\hline D1 & -3.956 & -5.657 & 1.701 \\
D2 & -3.867 & -5.682 & 1.815 \\
D3 & -3.694 & -4.869 & 1.175 \\
D4 & -3.840 & -5.180 & 1.340 \\
\hline
\end{tabular}

\section{Results and Discussion}

5.1. Energy Levels of Photosensitizers. The frontier molecular orbital (FMO) of dyes provides the necessary driving force for the charge transfer. We used a DFT technique to find the band gaps of $\mathrm{TiO}_{2}$ cluster and novel photosensitizers. The electron distribution of the HOMOs and LUMOs of D1, D2, D3, and D4 is shown in Figure 2. Clearly, the HOMOs of these compounds are the highest electron density located at donor moieties. The LUMOs are located in the anchoring group through the pi-bridge. Thus, the HOMO-LUMO excitation induced by light irradiation could move the electron distribution from the donor moieties to the anchoring unit through the pi-bridge segment. $\left(\mathrm{TiO}_{2}\right)_{8}$ cluster was also simulated to find its conduction band $(-4.0 \mathrm{eV})$ and band gap $(3.18 \mathrm{eV})$.

Table 1 shows that the HOMOs of sensitizers are in the sequence of D3 $(-4.689)>\mathrm{D} 4(-5.180)>\mathrm{D} 1(-5.657)>\mathrm{D} 2$ $(-5.682)$. The LUMOs energy levels are in the sequence of D3 $(-3.694)>\mathrm{D} 4(-3.840)>\mathrm{D} 2(-3.867)>\mathrm{D} 1(-3.956)$. The electron-donating moieties significantly affect the HOMO and LUMO energy levels of the dyes. Similarly, the $\mathrm{H}-\mathrm{L}_{\text {gap }}$ of the dyes are in the order of D3 $(1.175)<\mathrm{D} 4(1.340)<\mathrm{D} 1$ $(1.701)<$ D2 (1.815). These results suggest that dyes $1-4$ can inject electrons to the conduction band of titanium oxide.

5.2. Absorption Spectra of Dyes. The absorption spectra of D3 in chloroform and adsorbed on $\mathrm{TiO}_{2}$ are shown in Figure 3. Two distinct absorption bands of D3 in chloroform can be observed: one relatively weak band is in the region (380$400 \mathrm{~nm}$ ) corresponding to the $\pi-\pi^{*}$ electron transitions of the conjugated molecules and the other is around 430$460 \mathrm{~nm}$ that can be assigned to an intramolecular charge transfer (ICT) between electron-donor and electron acceptor anchoring moieties. However, the absorption shifts to lower energy values when anchored to $\mathrm{TiO}_{2}$. This is due to the fact that on the electrode the carboxylate groups bind to the $\mathrm{TiO}_{2}$ surface in which $\mathrm{Ti}^{4+}$ acts as proton. The interaction between the carboxylate group and the surface $\mathrm{Ti}^{4+}$ ions may lead to increased delocalization of the $\pi^{*}$ orbital. The energy of the $\pi^{*}$ level is decreased by this delocalization, which explains the red shift for the absorption spectra.

5.3. Photovoltaic Performance. DSSCs were fabricated using D1, D2, D3, and D4 dyes having an effective area of $0.35 \mathrm{~cm}^{2}$. The photovoltaic parameters of DSSCs are recorded in Table 2 and the corresponding photocurrent voltage $(J-V)$ characteristics are showed in Figure 4. Solar cell based on D3 sensitizer shows the best performance among the four dyes. It can be 
TABLE 2: PV properties of DSSCs.

\begin{tabular}{lcccc}
\hline Dyes & $j_{\mathrm{sc}}\left(\mathrm{mA} / \mathrm{cm}^{2}\right)$ & $V_{\mathrm{oc}}(\mathrm{mV})$ & $\mathrm{FF}(\%)$ & $\eta(\%)$ \\
\hline D1 & 0.479 & 448 & 50 & 0.11 \\
D2 & 0.952 & 455 & 51 & 0.23 \\
D3 & 8.178 & 632 & 50 & 2.58 \\
D4 & 2.196 & 587 & 40 & 0.52 \\
\hline
\end{tabular}

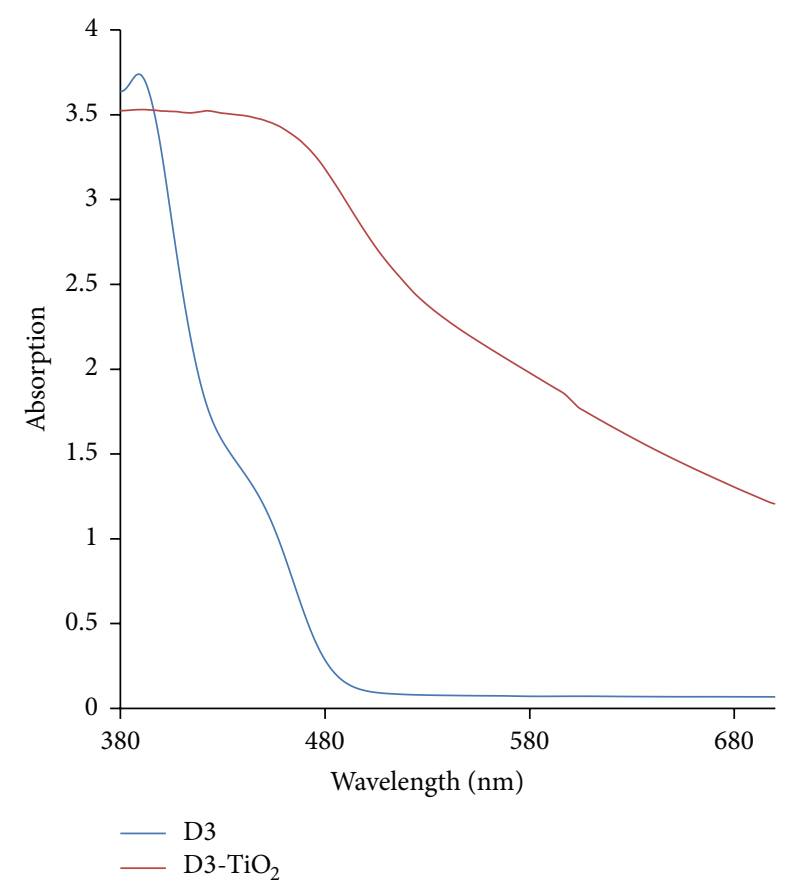

FIGURE 3: Absorption spectra of D3 in chloroform and anchored to $\mathrm{TiO}_{2}$.

clearly seen that the electron donor moiety of dyes plays a key role in the photovoltaic performance. Thus, introducing the anthracene unit as an electron donor moiety improves the photocurrent of DSSC. Moreover, the higher HOMO and LUMO energy levels of D3 do not only generate charge separation but also accelerate the dye regeneration to avoid charge recombination.

5.4. EIS Analysis. EIS analysis is performed to investigate the interface resistances in DSSCs. Figure 5 shows the Nyquist plot of DSSCs which were assembled with novel photosensitizers. Generally, a normal impedance spectrum of DSSCs is represented by three arcs (semicircles). The first semicircle represents the resistance of electron transfer at counter electrode/electrolyte $\left(R_{1}\right)$, second signifies the resistance of charge transfer at the photoanode/electrolyte interface $\left(R_{2}\right)$, and third indicates the diffusion of $\mathrm{I}^{-} / \mathrm{I}_{3}{ }^{-}$in electrolyte $(Z w)[26,27]$. Only second arc comes out in the Nyquist plot in Figure 5. It is probable that the other two arcs corresponding to $R_{1}$ and $Z w$ are overshadowed by large semicircle representing $R_{2}[28,29]$. The $R_{2}$ signifies the charge recombination rate; for example, a larger $R_{2}$ specifies a slower charge recombination. The $R_{2}$ value for DSSC assembled with

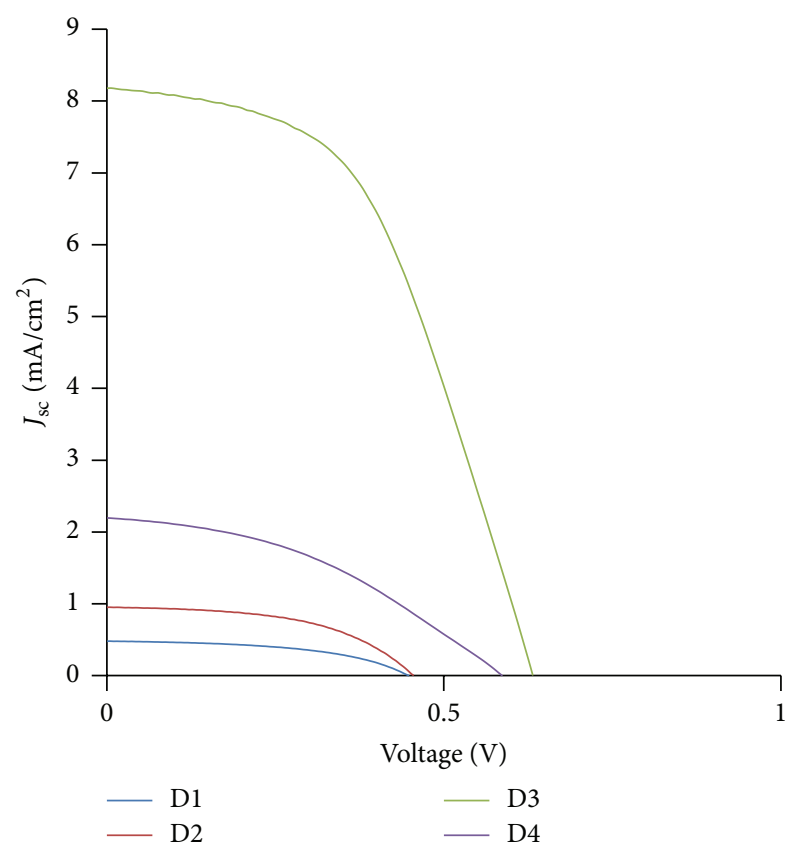

FIgURE 4: Current-voltage curves of DSSCs.

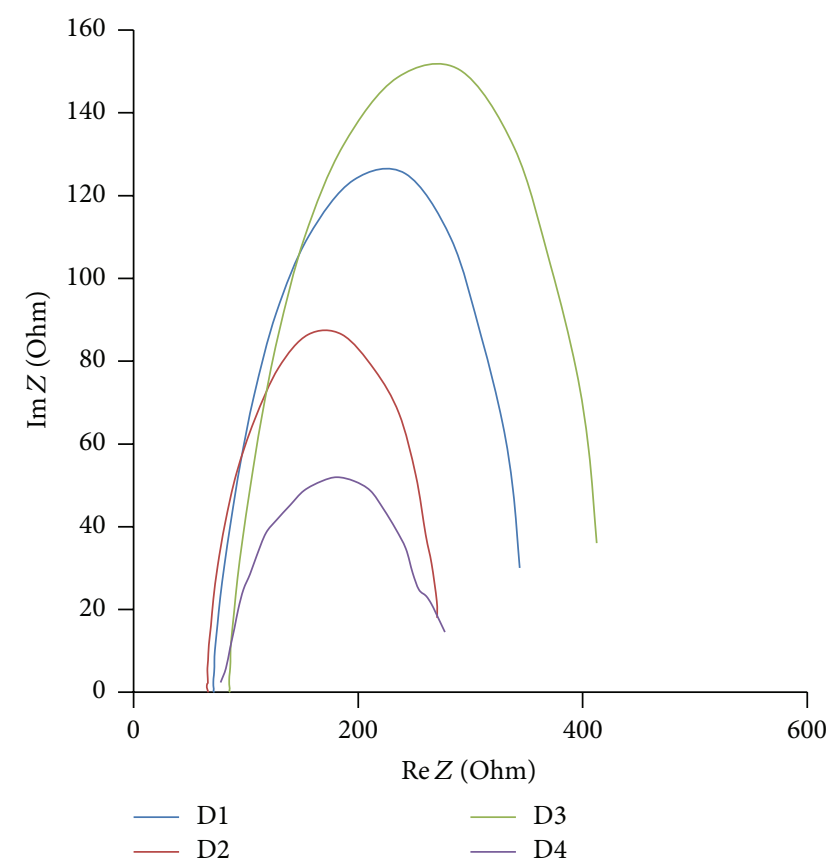

FIGURE 5: Nyquist plots of the DSSCs.

$\mathrm{D} 3$ is greater that of $\mathrm{D} 1, \mathrm{D} 2$, and $\mathrm{D} 4$. The higher $R_{2}$ of $\mathrm{D} 3$ relative to D1, D2, and D3 could be attributed to the steric hindrance of bulky anthracene unit.

\section{Conclusion}

A series of novel dyes D1, D2, D3, and D4 have been prepared for DSSCs. The results indicate that the donor moiety in organic dyes strongly influences the performance of DSSCs. 
The incorporation of anthracene unit as a donor moiety improves the efficiency of DSSC as compared to other donor units, that is, biphenyl, naphthalene, and triphenylamine. Among the four photosensitizers synthesized, maximum efficiency of $2.58 \%$ was obtained with DSSCs based on D3 $\left(J_{\mathrm{sc}}=8.178 \mathrm{~mA} / \mathrm{cm}^{2}, V_{\mathrm{oc}}=632 \mathrm{mV}, \mathrm{FF}=0.5\right)$. These results advocates that the photosensitizers based on anthracene unit are auspicious candidates for DSSCs.

\section{Conflict of Interests}

The authors declare that there is no conflict of interests regarding the publication of this paper.

\section{Acknowledgments}

The authors would like to acknowledge the funding provided by King Abdulaziz City for Science and Technology (KACST) through Project no. 11-ENE1635-04 as part of the National Science, Technology and Innovation Plan. The authors would like to acknowledge the Center of Research Excellence for Renewable Energy at KFUPM.

\section{References}

[1] B. O’Regan and M. Grätzel, "A low-cost, high-efficiency solar cell based on dye-sensitized colloidal $\mathrm{TiO}_{2}$ films," Nature, vol. 353, pp. 737-740, 1991.

[2] N. Robertson, "Optimizing dyes for dye-sensitized solar cells," Angewandte Chemie-International Edition, vol. 45, no. 15, pp. 2338-2345, 2006.

[3] A. Hagfeldt, G. Boschloo, L. Sun, L. Kloo, and H. Pettersson, "Dye-sensitized solar cells," Chemical Reviews, vol. 110, no. 11, pp. 6595-6663, 2010.

[4] C. Klein, M. K. Nazeeruddin, P. Liska et al., "Engineering of a novel ruthenium sensitizer and its application in dye-sensitized solar cells for conversion of sunlight into electricity," Inorganic Chemistry, vol. 44, no. 2, pp. 178-180, 2005.

[5] U. Mehmood, S. Ahmed, I. A. Hussein, and K. Harrabi, "Cosensitization of $\mathrm{TiO}_{2}$-MWCNTs hybrid anode for efficient dyesensitized solar cells," Electrochimica Acta, vol. 173, pp. 607-612, 2015.

[6] U. Mehmood, S. Ahmed, I. A. Hussein, and K. Harrabi, "Improving the efficiency of dye sensitized solar cells by $\mathrm{TiO}_{2}$ graphene nanocomposite photoanode," Photonics and Nanostructures-Fundamentals and Applications, vol. 16, pp. 34-42, 2015.

[7] U. Mehmood, K. Harrabi, I. A. Hussein, and S. Ahmed, "Enhanced photovoltaic performance of dye-sensitized solar cells using $\mathrm{TiO}_{2}$-graphene microplatelets hybrid photoanode," IEEE Journal of Photovoltaics, 2015.

[8] M. K. Nazeeruddin, F. De Angelis, S. Fantacci et al., "Combined experimental and DFT-TDDFT computational study of photoelectrochemical cell ruthenium sensitizers," Journal of the American Chemical Society, vol. 127, no. 48, pp. 16835-16847, 2005.

[9] F. Gao, Y. Wang, D. Shi et al., "Enhance the optical absorptivity of nanocrystalline $\mathrm{TiO}_{2}$ film with high molar extinction coefficient ruthenium sensitizers for high performance dyesensitized solar cells," Journal of the American Chemical Society, vol. 130, no. 32, pp. 10720-10728, 2008.

[10] C.-Y. Chen, M. Wang, J.-Y. Li et al., "Highly efficient lightharvesting ruthenium sensitizer for thin-film dye-sensitized solar cells," ACS Nano, vol. 3, no. 10, pp. 3103-3109, 2009.

[11] U. Mehmood, S.-U. Rahman, K. Harrabi, I. A. Hussein, and B. V. S. Reddy, "Recent advances in dye sensitized solar cells," Advances in Materials Science and Engineering, vol. 2014, Article ID 974782, 12 pages, 2014.

[12] C. Wang, G.-Y. Jung, Y. Hua et al., "An efficient pyridineand oxadiazole-containing hole-blocking material for organic light-emitting diodes: synthesis, crystal structure, and device performance," Chemistry of Materials, vol. 13, no. 4, pp. 11671173, 2001.

[13] Z. Tian, M. Huang, B. Zhao et al., "Low-cost dyes based on methylthiophene for high-performance dye-sensitized solar cells," Dyes and Pigments, vol. 87, no. 3, pp. 181-187, 2010.

[14] M. Mao, J.-B. Wang, Z.-F. Xiao, S.-Y. Dai, and Q.-H. Song, "New 2,6-modified BODIPY sensitizers for dye-sensitized solar cells," Dyes and Pigments, vol. 94, no. 2, pp. 224-232, 2012.

[15] S. Qu, B. Wang, F. Guo et al., "New diketo-pyrrolo-pyrrole (DPP) sensitizer containing a furan moiety for efficient and stable dye-sensitized solar cells," Dyes and Pigments, vol. 92, no. 3, pp. 1384-1393, 2012.

[16] G. te Velde, F. M. Bickelhaupt, E. J. Baerends et al., "Chemistry with ADF," Journal of Computational Chemistry, vol. 22, no. 9, pp. 931-967, 2001.

[17] J. Wang, H. Li, N.-N. Ma, L.-K. Yan, and Z.-M. Su, "Theoretical studies on organoimido-substituted hexamolybdates dyes for dye-sensitized solar cells (DSSC)," Dyes and Pigments, vol. 99, no. 2, pp. 440-446, 2013.

[18] W. Fan, D. Tan, and W.-Q. Deng, "Acene-modified triphenylamine dyes for dye-sensitized solar cells: a computational study," ChemPhysChem, vol. 13, no. 8, pp. 2051-2060, 2012.

[19] W. Sang-aroon, S. Saekow, and V. Amornkitbamrung, "Density functional theory study on the electronic structure of Monascus dyes as photosensitizer for dye-sensitized solar cells," Journal of Photochemistry and Photobiology A: Chemistry, vol. 236, pp. 3540, 2012.

[20] X. Zarate, E. Schott, T. Gomez, and R. Arratia-Pérez, “Theoretical study of sensitizer candidates for dye-sensitized solar cells: peripheral substituted dizinc pyrazinoporphyrazinephthalocyanine complexes," The Journal of Physical Chemistry A, vol. 117, no. 2, pp. 430-438, 2013.

[21] U. Mehmood, I. A. Hussein, M. Daud, S. Ahmed, and K. Harrabi, "Theoretical study of benzene/thiophene based photosensitizers for dye sensitized solar cells (DSSCs)," Dyes and Pigments, vol. 118, pp. 152-158, 2015.

[22] U. Mehmood, I. A. Hussein, K. Harrabi, and B. V. Reddy, "Density functional theory study on dye-sensitized solar cells using oxadiazole-based dyes," Journal of Photonics for Energy, vol. 5, no. 1, Article ID 053097, 2015.

[23] D. Rocca, R. Gebauer, F. De Angelis, M. K. Nazeeruddin, and S. Baroni, "Time-dependent density functional theory study of squaraine dye-sensitized solar cells," Chemical Physics Letters, vol. 475, no. 1-3, pp. 49-53, 2009.

[24] U. Mehmood, I. A. Hussein, K. Harrabi, M. Mekki, S. Ahmed, and N. Tabet, "Hybrid $\mathrm{TiO}_{2}-$ multiwall carbon nanotube (MWCNTs) photoanodes for efficient dye sensitized solar cells (DSSCs)," Solar Energy Materials and Solar Cells, vol. 140, pp. 174-179, 2015. 
[25] U. Mehmood, I. A. Hussein, K. Harrabi, and S. Ahmed, "Density functional theory study on the electronic structures of oxadiazole based dyes as photosensitizer for dye sensitized solar cells," Advances in Materials Science and Engineering, vol. 2015, Article ID 286730, 8 pages, 2015.

[26] K. Lee, C. Hu, H. Chen, and K. Ho, "Incorporating carbon nanotube in a low-temperature fabrication process for dyesensitized $\mathrm{TiO}_{2}$ solar cells," Solar Energy Materials and Solar Cells, vol. 92, no. 12, pp. 1628-1633, 2008.

[27] Y.-L. Xie, Z.-X. Li, Z.-G. Xu, and H.-L. Zhang, "Preparation of coaxial $\mathrm{TiO}_{2} / \mathrm{ZnO}$ nanotube arrays for high-efficiency photoenergy conversion applications," Electrochemistry Communications, vol. 13, no. 8, pp. 788-791, 2011.

[28] S. Li, Y. Lin, W. Tan et al., "Preparation and performance of dyesensitized solar cells based on $\mathrm{ZnO}$-modified $\mathrm{TiO}_{2}$ electrodes," International Journal of Minerals, Metallurgy, and Materials, vol. 17, no. 1, pp. 92-97, 2010.

[29] A. S. Nair, R. Jose, Y. Shengyuan, and S. Ramakrishna, "A simple recipe for an efficient $\mathrm{TiO}_{2}$ nanofiber-based dye-sensitized solar cell," Journal of Colloid and Interface Science, vol. 353, no. 1, pp. 39-45, 2011. 

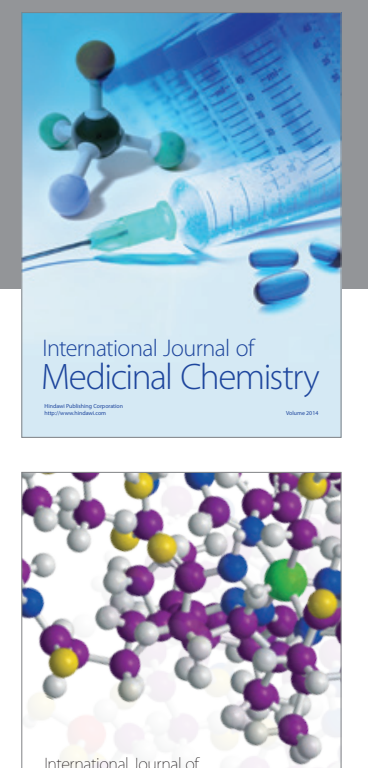

\section{Carbohydrate} Chemistry

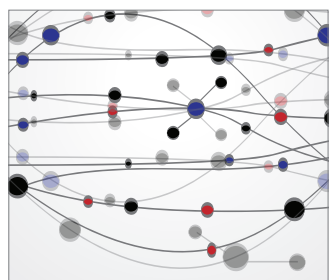

The Scientific World Journal
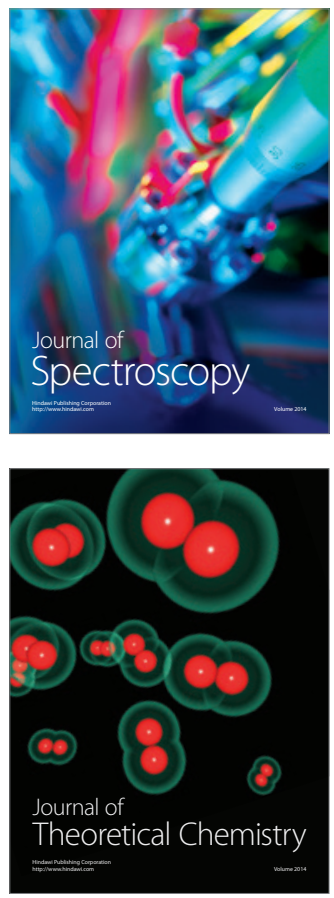
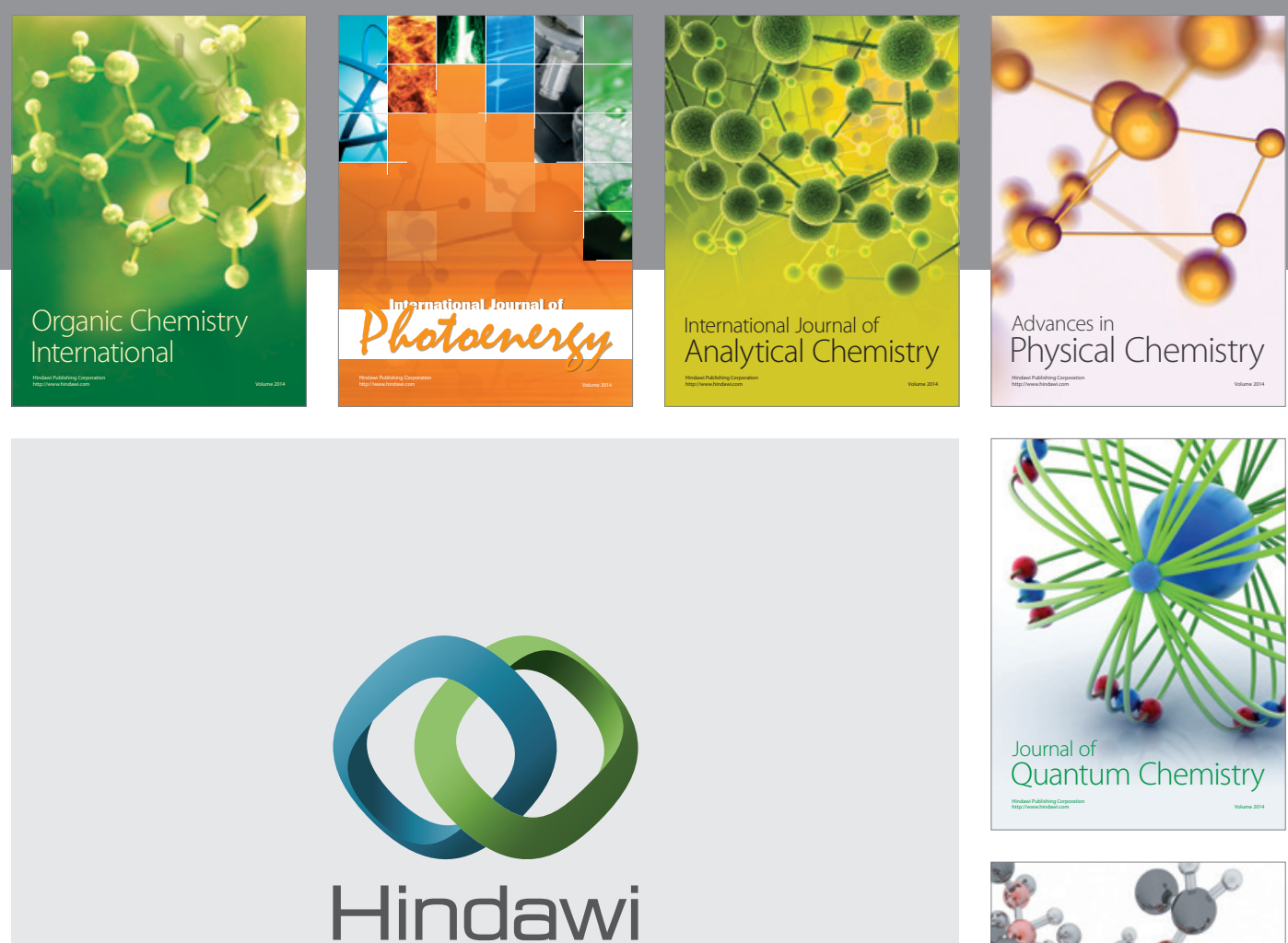

Submit your manuscripts at

http://www.hindawi.com

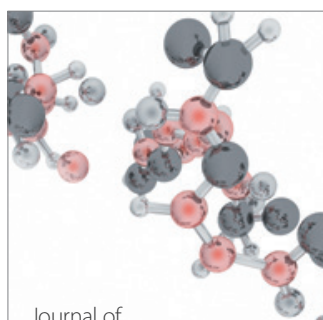

Analytical Methods

in Chemistry

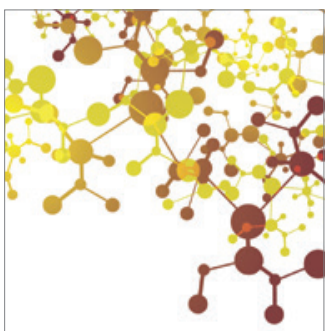

Journal of

Applied Chemistry

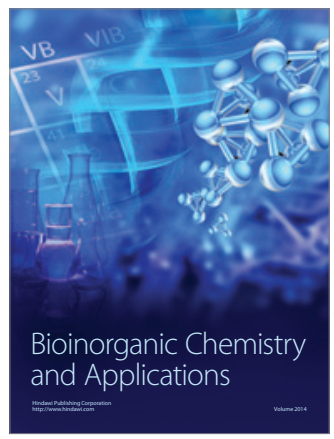

Inorganic Chemistry
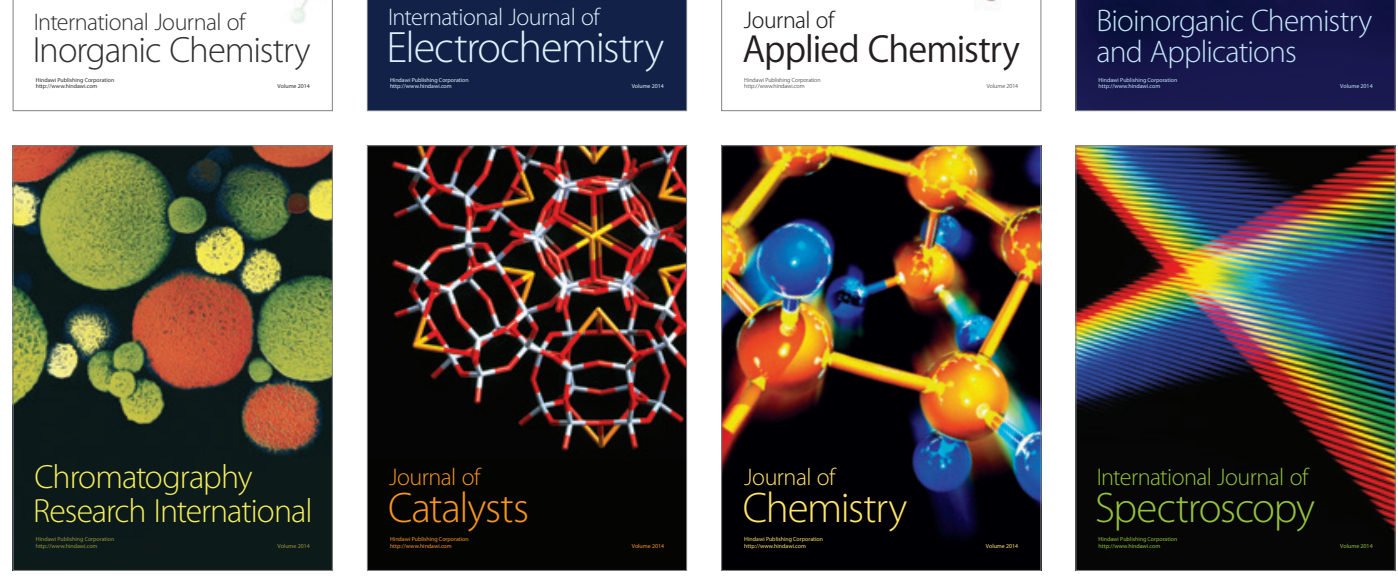